\title{
Implementasi Kebijakan Penggunaan Sistem Informasi Perencanaan Pembangunan Daerah Di Kota Dumai (Studi Kasus Pada Aplikasi E- Planning)
}

\author{
Lusi Adriani \\ Fakultas Ilmu Sosial dan Ilmu Politik, Universitas Riau \\ Korespondensi :uciriadimas28210@gmail.com
}

\begin{abstract}
Abstrak
Musyawarah Perencanaan dan Pembangunan (Musrenbang) adalah forum musyawarah dalam menentukan program prioritas dan strategi pencapaian program di tingkat Kecamatan dan dikemas dengan menggunakan aplikasi E-Planning. Dalam proses tersebut terdapat singkronisasi alokasi program pembangunan dan kebutuhan masyarakat. Tujuan penelitian ini yaitu mengetahui Implementasi Kebijakan Penggunaan Sistem Informasi Perencanaan Pembangunan Daerah di Kota Dumai (studi kasus pada aplikasi eplanning) dan Untuk mengetahui faktor penghambat dari Implementasi Kebijakan Penggunaan Sistem Informasi Perencanaan Pembangunan Daerah di Kota Dumai (studi kasus pada aplikasi eplanning). Metode penelitian yang digunakan dalam penelitian ini adalah metode kuantitatif. Berdasarkan hasil penelitian yang dianalisis dengan teori impementasi kebijakan dari subarsono terdiri dari 4 indikator yaitu komunikasi, sumberdaya, disposisi dan system birokasi. Serta terdapat penghambat masih kurangnya fasilitas tata ruang serta titik koordinat untuk menghitung data secara spasial dan juga mengolah usulan perencanaan sesuai dengan kewilayahan yang ada. usulan perencanaan pembangunan mengenai pembangunan kewilayahan masih terkendala karena perangkat daerah tidak berani melaksanakan kegiatan tersebut diakibatkan sistem ini belum mengakomodir bahkan sampai titik spasial.
\end{abstract}

Kata Kunci : E-Planning, Kecamatan, Musrenbang.

\begin{abstract}
The Planning and Development Deliberation (Musrenbang) is a forum for deliberation in determining priority programs and program achievement strategies at the District level and packaged using the E-Planning application. In this process there is a synchronization of the allocation of development programs and community needs. The purpose of this study is to find out the implementation of policies on the use of information systems for regional development planning in Dumai City (a case study on the eplanning application) and to find out the inhibiting factors of the implementation of policies on the use of information systems for regional development planning in the city of Dumai (a case study on the eplanning application). The research method used in this study is a quantitative method. Based on the research results, which were analyzed using the theory of policy implementation from Subarsono, it consisted of 4 indicators, namely communication, resources, disposition and bureaucratic systems. And there are obstacles that are still lacking in spatial planning facilities and coordinate points to calculate data spatially and also process planning proposals in accordance with existing regions. The proposed development planning regarding regional development is still constrained because the regional apparatus does not dare to carry out these activities because this system has not accommodated even to the spatial point.
\end{abstract}

Keywords: E-Planning, District, Musrenbang. 


\section{PENDAHULUAN}

Berdasarkan Undang-Undang Nomor 25 Tahun 2005 tentang Sistem Perencanaan Pembangunan Nasional menjelaskan bahwa perencanaan pembangunan merupakan kegiatan dalam menentukan arah kebijakan yang sesuai dengan kebutuhan masyarakat dengan berbagai metode dan alur kegiatan yang sistematis dengan melihat kualitas sumber daya yang dimiliki. Pentingnya proses perencanaan pembangunan daerah menandakan setiap daerah dituntut untuk dapat menimalisir kesalahan-kesalahhan yang akan terjadi dalam proses pembangunan, sehingga diharapkan pembangunan daerah dapat berjalan lebih efektif sesuai yang ditelah direncanakan. Pemasalahan dimasing - masing daerah akan berbeda beda pada proses perencanaan sehingga kondisi ini menunjukkan bahwa proses perencanaan pembangunan daerah sangat behubungan erat dengan isu - isu strategis dan karateristik daerah itu sendiri. Proses perencanaan pembangunan daerah musrenbang salah satunya cara yang dilakukan untuk menampung rencana pembangunan usulan masyarakat mulai dari tingkat kelurahan dan kecamatan pada saat akan dilaksanakannya Forum Perangkat Daerah yang di proses secara bottom upserta mampu menampung usulan Pokok-pokok Pikiran (Pokir) DPRD yang telah terakomodir seminggu sebelum dilaksanakannya Musrenbang RKPD. Terbatasnya waktu dan terlalu panjangnya proses penyusunan sesuai edaran permendagri dimaksud, maka Pemerintah Kota Dumai melakukan inovasi dalam proses penyusunan perencanaan pembangunan tanpa mengurangi keakuratan data serta ketepatan waktu yang diberikan pemerintah Daerah. Dalam Proses Perencanaan Pembangunan Kota Dumai menggunakan aplikasi berbasis komputer yang dinamakan ePlanning guna mendukung dan membantu proses penyusunan perencanaan daerah di Kota Dumai. Penggunaan Sistem Informasi e-planning merupakan suatu bagian dari perwujudan integrasi data perencanaan yang dapat mendokumentasikan tahapan proses perencanaan dalam jangka waktu tertentu dan menetapkan rencana program, kegiatan tahunan daerah sebagai rujukan bersama untuk seluruh pemangku kepentingan pembangunan. Dalam aplikasi ini masih terjadi beberapa kendala dalam beberapa tahapan perencanaan pembangunan. System Informasi ini melibatkan unsur pemerintah daerah (eksekutif dan legislatif), kalangan masyarakat, dan kalangan swasta. Sebagai perangkat daerah yang mempunyai fungsi penunjang perencanaan pembangunan daerah, Bappeda Kota Dumai dalam rangka menyusun kebijakan perencanaan pembangunan daerah membutuhkan data dan informasi yang digunakan sebagai bahan pertimbangan dalam menyusun dokumen perencanaan daerah seperti RPJPD, RPJMD, dan RKPD.

\section{METODE}

Penelitian yang digunakan adalah penelitian kualitatif dengan pendekatan studi kasus dimana akan dilakukan secara mendalam terhadap program, kejadian, proses, aktifitas, terhadap satu atau lebih orang (Surjadi, 2020:6). Peneliti akan mengumpulkan data secara terperinci dengan menggunakan berbagai prosedur pengumpulan data mengenai implementasi kebijakan penggunaan simreda kota dumai (eplanning) serta faktor-faktor yang menghambat sehingga nantinya akan menghasilkan data deksriptif berupa kata-kata tertulis maupun lisan dari orang-orang dan perilaku yang diamati.

Informan penelitian ini adalah Informan dalam penelitian ini adalah pegawai negeri sipil yang bertugas di

a. Sekretaris Bappeda Kota Dumai

b. Kasubbid Penelitian dan Kerjasama Bappeda Kota Dumai.

c. Kasubbag Perencanaan Dinas PU PR Kota Dumai

d. Kasubbag Perencanaan Dinas Disdikbud Kota Dumai

e. Kasubbag Perencanaan Kecamatan Dumai Kota 
Penelitian akan dilakukan pada Badan Perencanaan Pembangunan Daerah Kota Dumai yang beralamat di Jln. Tuanku Tambusai Komplek Perkantoran Walikota Dumai Bagan Besar, Kota Dumai dengan alas an ditemukannya beberapa fenomena yang berkaitan dengan implementasi kebijakan penggunaan simreda kota dumai (eplanning) serta mengingat tugas dan fungsinya sebagai perangkat daerah yang melaksanakan fungsi penunjang perencanaan pembangunan daerah sehingga memegang peranan yang cukup penting dalam proses perencanaan pembangunan di Kota Dumai.

\section{HASIL DAN PEMBAHASAN}

\section{A. Implementasi Kebijakan Penggunaan Sistem Informasi Perencanaan Pembangunan (e- planning)}

Adapun tujuan dilaksanakan sistem perencanaan pembangunan daerah (e-planning) ini adalah :

a. memberikan acuan pelaksana dan penggunaan aplikasi $e$-planning bagi seluruh OPD dan para pemangku kepentingan pembangunan daerah;

b. menciptakan konsistensi tahapan perencanaan pembangunan daerah;

c. mewujudkan transparansi, efektifitas, efisiensi dan akuntabilitas perencanaan pembangunan dalam rangka mendukung peningkatan kinerja pelayanan publik; dan

d. mendorong terjadinya tata kelola pemerintahan yang baik dan bersih dengan memanfaatkan teknologi informasi untuk menghasilkan secara konsisten hasil perencanaan yang berkualitas.

Setiap OPD harus mengikuti tahapan dan mekanisme pengusulan kegiatan sehingga tahapan dan proses e-planning. dalam proses perencanaan pembangunan daerah musrenbang salah satunya cara yang dilakukan untuk menampung rencana pembangunan usulan masyarakat mulai dari tingkat kelurahan dan kecamatan pada saat akan dilaksanakannya Forum Perangkat Daerah yang di proses secara bottom up serta mampu menampung usulan Pokok-pokok Pikiran (Pokir) DPRD yang telah terakomodir seminggu sebelum dilaksanakannya Musrenbang RKPD.

Pada tahap Mekanisme pengusulan kegiatan, OPD melakukan proses pada e-planning yaitu dengan melakukan verifikasi usulan kegiatan dari hasil musrenbang kecamatan dan kelurahan serta usulan eksternal. Lalu melakukan input/update/delete usulan renja awal terdiri dari usulan kegiatan OPD dan usulan eksternal OPD. Kemudian menyelaraskan usulan renja awal dengan isu strategis dalam dokumen perencanaan dan mengesahkan usulan renja awal menjadi renja akhir.

Sistem e-planning masih memberikan dampak kurang efisensi dan efektifnya serta tidak sistematis saat melakukan dinamika proses perencanaan pembangunan di Kota Dumai, masih banyaknya usulan musrenbang yang tidak tersistematis berakibat tidak optimalnya usulan musrenbang seperti yang terlihat pada usulan Musrenbang perkecamatan pada usulan musrenbang RKPD Tahun 2020 pada Tabel 5.1 dibawah ini :

Tabel 5.1 Usulan Musrenbang Kecamatan RKPD Tahun 2020

\begin{tabular}{cccccc}
\hline No & Kecamatan & Usulan & Disetujui & $\begin{array}{c}\text { Tidak } \\
\text { disetujui }\end{array}$ & $\begin{array}{c}\text { Sedang } \\
\text { diverifika } \\
\text { si }\end{array}$ \\
\hline 1. & Bukit Kapur & 194 & 57 & 129 & 8 \\
\hline 2 & Dumai Barat & 98 & 32 & 63 & 3 \\
\hline
\end{tabular}




\begin{tabular}{clcccc}
\hline 3. & Dumai Kota & 106 & 24 & 55 & 27 \\
\hline 4. & Dumai Selatan & 292 & 47 & 201 & 44 \\
\hline 5. & Dumai Timur & 21 & 8 & 13 & 0 \\
\hline 6. & $\begin{array}{l}\text { Medang } \\
\text { Kampai }\end{array}$ & 399 & 64 & 320 & 15 \\
\hline 7. & Sei. Sembilan & 993 & 122 & 761 & 110 \\
\hline & Total & $\mathbf{2 . 1 0 3}$ & $\mathbf{3 5 4}$ & $\mathbf{1 5 4 2}$ & $\mathbf{2 0 7}$ \\
\hline
\end{tabular}

Penyusunan perencanaan pembangunan daerah berpedoman pada rencana tata ruang wilayah sehingga dalam implementasinya dapat diartikan bahwa perencanaan pembangunan daerah pada prinsipnya bertujuan mengintegrasikan rencana tata ruang wilayah dengan rencana pembangunan daerah. Namun sampai saat ini, aplikasi e-planning belum memiliki menu sinkronisasi dengan pendekatan spasial sebagai alat untuk melakukan penelaahan terhadap Rencana Tata Ruang Wilayah khususnya pola ruang.

Adapun implementasi dari kebijakan penggunaan Simreda di Kota Dumai dibahas menggunakan teori implementasi kebijakan dari subarsono yang terdiri dari empat indikator yaitu :

\section{Komunikasi}

Komunikasi adalah proses menciptakan informasi dimana beberapa orang dan sekelompok akan saling terhubung dan saling berinteraksi dengan lingkungan sekitar informasi dapat secara verbal dan memahami kedua belah pihak yang saling berkaitan, dalam komunikasi merupakan suatu perilaku dalam bentuk simbolik maupun lisan untuk mendapatkan respon atau efek yang mereka inginkan, dalam komunikasi juga akan terbentuk sebuah proses pemeliharaan atau pengubahan sehingga tersampaikan sebuah maksud dengan kesesuaian aturan tertentu. Badan perencanaan pembangunan daerah Kota Dumai menetapkan komunikator sebagai orang yang mampu mensosialisasikan iklan yang ini dan harus memiliki pemahaman yang baik terhadap penggunaan aplikasi e-planning. sosialisasi dilakukan bukan hanya untuk bagian internal dalam Bappeda Kota Dumai namun juga kepada eksternal, kegiatan ini biasanya dilaksanakan secara formal dalam bentuk pelatihan serta kegiatan formal untuk sosialisasi internal Bappeda itu sendiri sehingga akan dapat diketahui cara penggunaan serta kendala yang ditemui dalam penggunaan planning. dalam penggunaan e planning memiliki admin super di mana iya harus paham lebih dulu penggunaan aplikasi agar tidak terjadi kesalahan penyampaian informasi kepada para pengguna lainnya. admin yang ditunjuk untuk menjalankan planning biasanya adalah perwakilan dari tiap-tiap bidang dan menjadi operator sehingga merekalah yang diutamakan untuk mengikuti kegiatan sosialisasi ini. 
Gambar. Tahapan perencanaan anggaran pembangunan

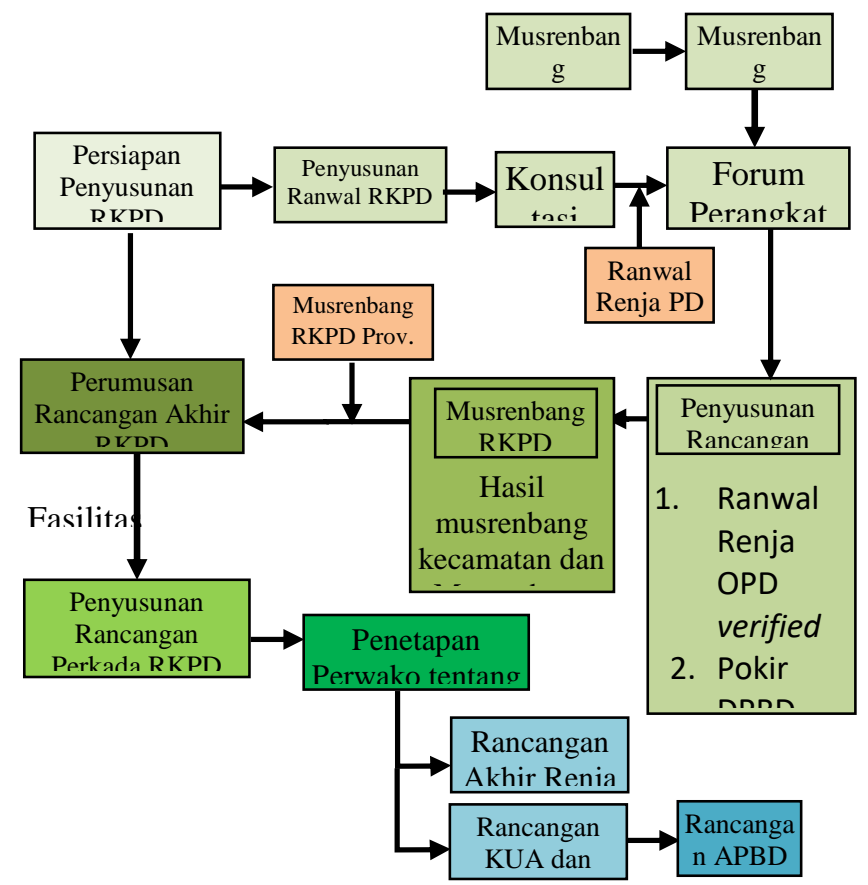

proses perencanaan pembangunan daerah musrenbang salah satunya cara yang dilakukan untuk menampung rencana pembangunan usulan masyarakat mulai dari tingkat kelurahan dan kecamatan pada saat akan dilaksanakannya Forum Perangkat Daerah yang di proses secara bottom up serta mampu menampung usulan Pokok-pokok Pikiran (Pokir) DPRD yang telah terakomodir seminggu sebelum dilaksanakannya Musrenbang RKPD.

Tahap Mekanisme pengusulan kegiatan, OPD melakukan proses pada e-planning yaitu dengan melakukan verifikasi usulan kegiatan dari hasil musrenbang kecamatan dan kelurahan serta usulan eksternal. Lalu melakukan input/update/delete usulan renja awal terdiri dari usulan kegiatan OPD dan usulan eksternal OPD. Kemudian menyelaraskan usulan renja awal dengan isu strategis dalam dokumen perencanaan dan mengesahkan usulan renja awal menjadi renja akhir.

\section{Sumber Daya}

anggaran yang telah ditetapkan untuk melaksanakan kebijakan aplikasi permainan ini karena yang dianggarkan pada rencana anggaran Bappeda Kota Dumai harus memiliki tenaga teknis atau tenaga ahli sebagai pengawasan dan tim untuk implementasi aplikasi planning ini dan ditetapkan dengan keputusan kepala Bappeda. Pada penerapan e-planning, pengguna sistem e-planning adalah pemerintah daerah yang memanfaatkan barang jasa, fasilitas atau informasi yang disediakan oleh aplikasi e-planning dan menyampaikan usulan melalui aplikasi tersebut. Yang bertanggung jawab pada pengelolaan aplikasi yaitu :

1. Kepala Bappeda sebagai penanggung jawab pengelolaan aplikasi e-planning. Bertanggung jawab dalam menyusun dan menetapkan rencana pembangunan daerah.

2. Super Admin atau admin bidang sebagai penanggungjawab harian pengelolaan sist mem e-planning. Super admin atau admin bidang ini dibutuhkan keahlian dalam mengendalikan dan mengevaluasi jalannya sistem infomasi peencanaan pembangunan daerah. 
3. Admin OPD sebagai penanggung jawab teknis aplikasi eplanning. Bertanggung jawab terhadap mengkoordinasikan pengelolaan aplikasi eplanning dilingkup OPD dan melakukan distibusi usulan eksternal kesetiap bidang pada OPD.

\section{Disposisi}

Disposisi merupakan kecenderungan yang memiliki konsekuensi yang penting dalam melaksanakan kebijakan agar lebih efektif. pelaksana dari yang mempunyai kecenderungan ini memiliki dukungan terhadap implementasi kebijakan. wujud disposisi ini merupakan salah satu bentuk sikap dari pelaksana kegiatan ini baik kecenderungan sikap yang positif maupun negatif hal ini akan menentukan hasil dari implementasi kebijakan yang akan dihadapi.

Pentingnya komitmen bagi pemerintah daerah yang mendukung penuh dengan adanya kebijakan penggunaan aplikasi ini sangatlah terbantu karena dibalik aplikasi ini memudahkan dari perangkat daerah dalam melakukan penyusunan dokumen perencanaan Selain itu perangkat daerah juga harus mengikuti petunjuk yang telah ditetapkan oleh Bappeda. dalam mengelola aplikasi dan menggunakan aplikasinya sesuai dengan manual book yang telah diberikan dan sosialisasi yang telah disampaikan. dalam penggunaan aplikasi ini masing-masing organisasi perangkat daerah diberi aturan yang ditetapkan yaitu diberikan waktu untuk membuka dan mengunci sistemnya kembali karena usulan yang diterima haruslah dengan jadwal-jadwal yang telah ditentukan agar waktu perencanaan dapat berjalan sesuai aturannya. jika pada organisasi perangkat daerah tidak mengikuti aturan tersebut maka usulan yang dikirimkan tidak dapat masuk kedalam dokumen perencanaan bahkan Bappeda pun tidak akan membuka kunci sistem apabila waktu yang diberikan tersebut telah habis.

\section{Sistem Birokrasi}

Birokrasi merupakan bagian-bagian yang menjadi pelaksana serta terlibat dalam suatu kegiatan, identitas dari birokrasi bukan hanya disebut dalam struktur pemerintahan saja tetapi terdapat organisasi swasta institusi dan lembaga-lembaga yang terkait lainnya serta saling mempengaruhi dan saling membangun dalam kegiatan tertentu. Melakukan implementasi sebuah kebijakan harus bersifat yang kompleks karena hal ini menuntut dengan kerjasama yang dilibatkan oleh banyak pihak, jika kerjasama tersebut tidak terhubung dengan baik dan tidak berjalan secara kondusif maka bisa jadi implementasi suatu kebijakan akan berjalan dengan timpang serta menyebabkan tidak efektifnya struktur yang dijalankan dalam birokrasi tersebut. dalam penjelasan di atas menjelaskan bahwa posisi birokrasi merupakan tempat yang sangat fundamental dan mengkaji dalam implementasi kebijakan publik. adapun dalam pelaksanaan implementasi kebijakan sistem informasi manajemen perencanaan daerah Melalui aplikasi e-planning ini dan diselenggarakan di Kota Dumai memiliki pengaruh birokrasi yang kuat karena dalam pelaksanaan implementasi program ini terhubung beberapa lembaga instansi dan organisasi pemerintah daerah agar E-planning dapat terlaksana dengan baik.

Bappeda Kota Dumai sudah menjadi penanggung jawab dari planning dan kebijakan tersebut sudah diselenggarakan dan dirasakan telah cukup efektif dalam membantu melaksanakan perencanaan pembangunan daerah di Kota Dumai bersama dengan organisasi pemerintah daerah lainnya. namun dalam penyelenggaraan event yang masih terbilang cukup baru ini memang terdapat beberapa kendala serta membutuhkan penyesuaian yang cukup agar bisa diperbaiki kembali untuk masa yang akan datang sehingga fungsi dari penggunaan aplikasi ini dapat dimaksimalkan dengan baik. terdapat kesulitan dari para pengguna perangkat daerah untuk menentukan usulan yang diakomodir oleh dan ditolak dari inputan data yang tersimpan pada tahun sebelumnya dan menyebabkan mangkat daerah harus menginput ulang susunan usulan tersebut. 


\section{B. Faktor yang menghambat Implementasi Kebijakan Penggunaan Simreda Kota Dumai (e- planning)}

Implementasi dari aplikasi e-planning merupakan koneksi dari masing-masing organisasi perangkat daerah kepada Bappeda Kota Dumai hal ini nantinya akan dikelola oleh administrator perangkat dan dibantu oleh penanggung jawab aplikasi di Bappeda Kota Dumai namun dalam pelaksanaan ini masih terdapat kekurangan serta kendala yang terjadi di lapangan sehingga masih harus ada perbaharuan yang tepat terhadap penggunaan aplikasi ini.

beberapa kendala yang terjadi dalam pelaksanaan aplikasi ini yaitu masih tidak ada sistem record data dalam aplikasi ini karena bisa saja usulan dari kegiatan yang diusulkan pada tahun sebelumnya atau n-1 tidak diakomodir yang seharusnya tidak perlu di usulkan lagi Apabila ada sistem record data dari penginputan usulannya namun dari kenyataannya usulan yang tidak diakomodir tidak akan disimpan hal ini yang menyebabkan usulan tersebut harus diusulkan lagi pada tahun berikutnya sehingga terjadi pengulangan kerja dan pengulangan usulan kembali.

Aplikasi dibawah ini yang merupakan alat bantu dalam penyusunan dokumen serta perencanaan untuk memudahkan pekerjaan dalam perencanaan pembangunan yang lebih efektif yaitu dari manual ke elektronik, namun masih terdapat kelemahan dalam eksekusi hasil usulan masyarakat dan pokok pikiran dari DPRD bahwa manualnya usulan-usulan yang dimasukkan dan belum sepenuhnya dalam sistem otomatis. karena pancaran itu sendiri pada sistem tersebut belum bisa melihat serta belum dapat digambarkan dalam tata ruangnya dengan menilai usulan yang masuk di kawasan hutan atau kawasan lindung lainnya. belum adanya fasilitas penilaian tata ruang serta titik koordinat yang ada sehingga organisasi perangkat daerah tidak berani menurunkan usulan-usulan tersebut kondisi yang berbeda jika usulan mengenai kawasan hutan ataupun hutan lindung lainnya telah masuk dalam anggaran dari proses perencanaan, aplikasi perangkat daerah tetap tidak berani melaksanakan kegiatan tersebut karena dalam sistem ini belum mengakomodir bahkan sampai titik spasial.

\section{KESIMPULAN}

Perencanaan penyusunan pembangungan daerah dalam rangka pengelolaan dan pemanfaatan data serta informasi secara optimal badan perencanaan pembangunan daerah Kota Dumai bersama dengan daerah-daerah lainnya di Indonesia melakukan implementasi kebijakan public dengan penggunaan aplikasi E-planning sebagai sarana untuk membantu memudahkan pekerjaan dalam menyusun rencana pembangunan daerah untuk instansi terkait pemerintahan Kota Dumai bersama dengan organisasi perangkat daerah dan Bappeda Kota Dumai. Implementasi ini telah menjadi efektif dan bermanfaat serta terus dilakukan perbaikan dalan pengelolaannya agar lebih maksimal.

Adapun berdasarkan hasil penelitian yang telah dipaparkan melalui pengumpulan data wawancara serta observasi lapangan maka peneliti membahas penelitian ini dengan menggunakan teori Edward III sebagai implementasi aplikasi e-planning dianalisa melalui 5 indikator yaitu:

a. Komunikasi, Komunikasi yang dibentuk dan diciptakan antar organisasi pemerintah daerah dalam menjalankan aplikasi e-planning dapat melalui sosialisasi, komunikasi personal, serta adanya pembentukan kelompok khusus yang dibuat dalam pengoperasian E-Planning ini dirasakan sudah cukup baik serta komunikator yang dipilih dapat membantu pada operator menjalankan aplikasi ini.

b. Sumber Daya, Berbagai sumber daya yang telah disiapkan dalam pelaksanaan aplikasi ini dinyatakan juga sudah baik, karena tenaga pengendali serta admin yang sudah ditetapkan juga mendapatkan persejutuan langsung dari Bappeda Kota Dumai. 
c. Disposisi, Wujud disposisi ini merupakan salah satu bentuk sikap dari pelaksana kegiatan ini baik kecenderungan sikap yang positif maupun negatif hal ini akan menentukan hasil dari implementasi kebijakan yang akan dihadapi.

d. Sistem Birokrasi, Melalui aplikasi E-planning ini memiliki pengaruh birokrasi yang kuat karena dalam pelaksanaan implementasi program ini terhubung beberapa lembaga instansi dan organisasi pemerintah daerah agar E-planning terlaksana dengan baik. kebijakan tersebut sudah diselenggarakan dan dirasakan telah cukup efektif dalam membantu melaksanakan perencanaan pembangunan daerah di Kota Dumai bersama dengan organisasi pemerintah daerah lainnya.

Faktor Penghambat yang dirasakan dalam penggunaan aplikasi ini terhadap banyaknya serta opd Sebagai pengguna aplikasi e-planning bahwa masih kurangnya fasilitas tata ruang serta titik koordinat untuk menghitung data secara spasial dan juga mengolah usulan perencanaan sesuai dengan kewilayahan yang ada. usulan perencanaan pembangunan mengenai pembangunan kewilayahan masih terkendala karena perangkat daerah tidak berani melaksanakan kegiatan tersebut diakibatkan sistem ini belum mengakomodir bahkan sampai titik spasial.

\section{SARAN}

Dari penelitian yang telah peneliti lakukan Adapun beberapa saran yang ditujukan kepada beberapa pihak Sebagai penyelenggara dari pelaksanaan implementasi kebijakan publik aplikasi EPlanning ini, yaitu :

1. Badan perencanaan pembangunan daerah Kota Dumai haruslah melakukan upaya dalam mengatasi hambatan yang dirasakan oleh para pengguna Aplikasi e-planning yaitu dengan melakukan perbaikan serta menambahkan fasilitas titik koordinat agar memudahkan untuk penyusunan anggaran bagian kewilayahan.

2. Menambah fasilitas secara online untuk input data dari pengusulan masyarakat melalui tingkat kelurahan dan kecamatan hingga menampung usulan pokok-pokok pikiran DPRD yang telah diakomodir sebelumnya.

3. Melakukan pelatihan serta menjaga sistem komunikasi secara berkelanjutan agar pelaksanaan sistem aplikasi E-planning ini dapat berjalan dengan baik.

4. Meningkatkan kualitas sumber daya manusia agar para administrasi serta para user dapat terus mengupgrade seiring dengan diupgradenya kembali fasilitas aplikasi e-planning agar lebih lengkap dan lebih baik . 


\section{DAFTAR PUSTAKA}

[1] Abdul Wahab, Solichin. 2012. ANALISIS KEBIJAKAN: Dari Formulasi ke penyusunan Model-Model Implementasi Kebijakan Publik. Jakarta: PT. Bumi Aksara

[2] Abidin, Said Zainal. 2004. Kebijakan Publik. Jakarta : Pancur Siwah

[3] Agustino, Leo. 2006. Dasar-dasar Kebijakan Publik. Bandung: Alfabeta

[4] Dye, Thomas R. Understanding Public Policy, New Jersey: Prentice Hall. 2011

[5] Edi. Suharto. 2007. Kebijakan Sosial Sebagai Kebijakan Publik. Bandung: Alfabeta.

[6] Edward III, George C. 1980, Implementing Public Policy, Congressional Quarterly Press, Washington

[7] Indrajit, 2000. "Manajemen Sistem Informasi dan Teknologi Informasi," Pengantar Konsep Dasar,

[8] Moleong J. Lexi. 2006 Metode Penelitian Kualitatif. Bandung.

[9] Nugroho D, Riant. 2004. Kebijakan Publik, Formulasi, Implementasi, dan Evaluasi. Jakarta : Gramedia

[10] Salahuddin, M., \& Rusli., A. (2005). Information Systems Planning For E government In Indonesia. In The Second International Conference on Innovations in Information Technology (IIT' 05).

[11] Setiyadi, M. W. R. 2003. E Government sebagai suatu Investasi

[12] Subarsono, 2009.Analisis Kebijakan Publik.Yogyakarta:Pustaka Pelajar

[13] Tachjan. 2006. Implementasi Kebijakan Publik. Bandung: AIPI.

[14] Wayne parsons. 2006. Publik Policy: Pengantar Teori dan Praktik Analisis Kebijakan. Jakarta: Kencana Prenada Media Group

[15] Widodo. 2010. Analisis Kebijakan Publik.Jakarta : PT Bumi Aksara

[16] Winarno, Budi. 2007. Kebijakan Publik (teori dan Proses). Jakarta : PT. Buku Kita

[17] Winarwo. Budi 2008 . Implementasi Kebijakan Public, yongyarkarta : CAPS

[18] Undang-Undang Dasar Negara Kesatuan Republik Indonesia Tahun 1945 